\title{
Intoxicație cu litiu în context infecțios la un pacient în tratament cronic cu carbonat de litiu
}

\author{
Mihaela Zaharia' ${ }^{1}$, Augustin Cupşa ${ }^{1}$, Corneliu P. Popescu ${ }^{1,2}$, \\ Ionuț Vlad ${ }^{3}$, Simin Florescul ${ }^{1,2}$, Emanoil Ceauşu ${ }^{1}$ \\ ${ }^{1}$ Spitalul Clinic de Boli Infecţioase şi Tropicale \\ „Dr. Victor Babeş", Bucureşti, România \\ Universitatea de Medicină şi Farmacie „Carol Davila“, Bucureşti, România \\ ${ }^{3}$ Facultatea de Medicină Generală, Oradea, România
}

\begin{abstract}
REZUMAT
Introducere. Istoria utilizării sărurilor de Litiu în medicină a început în anii 1850 prin utilizarea acestuia pentru tratarea gutei. Cum mania şi melancolia au fost incluse în grupul aceloraşi diagnostice, Litiul a început să fie folosit şi în afecțiunile psihiatrice. La ora actuală, Litiul este încă folosit în tulburarea afectivă bipolară şi ca medicație adjuvantă în depresie, schizofrenie şi în tulburările schizo-afective, dar şi în controlul agresivității infantile.

Metode şi obiective. Prezentarea unui caz de intoxicație cu Litiu la un pacient cu infecție bacteriană şi tratament cronic cu litiu.

Obiective. Raportarea unui caz de intoxicație cu Litiu în context de angină eritemato-pultacee la un pacient în tratament cronic cu Carbonat de Litiu pentru episoade depresive cu elemete psihotice.

Concluzii. În practica medicală, intoxicația cu săruri de Litiu este rară în contextul folosirii înalt selective şi a dozării stricte a nivelului plasmatic al Litiului. În cazul prezentat aici, infecția bacteriană activă (angină pultacee) însoțită de febră, incapacitatea pacientului de a se hidrata adecvat şi uşoara insuficiență renală pe care a prezentat-o în contextul septic, a fost un trigger al mecanismului patogenic al intoxicației cu Litiu la acest pacient. Secundar insuficienței renale, excreția Litiului a fost deficitară, iar secundar sindromului de deshidratare, valoarea serică a Litiului a crescut şi mai mult prin scăderea volumului intravascular. În evoluție, apariția tulburărilor gastrointestinale au contribuit la cercul vicios între aportul hidroelectrolitic, excreție şi litemie renală.
\end{abstract}

Cuvinte cheie: infecție, angină streptococică, Litiu, intoxicație, manifestări neurologice

\section{INTRODUCERE}

În perioada 1840-1865, Litiul era folosit pentru tratamentul gutei. Când mania și melancolia $\mathrm{au}$ fost introduse în grupul bolilor gutoase, au început să fie tratate cu săruri de Litiu. În anii 1920, pshiatrul H.J. Schou demonstrează ineficiența profilactică a Litiului în depresie și Litiul este evitat. În anii 1950, Litiul reîncepe să fie prescris în SUA, în bolile afective, dar prescrierea lui devine din nou limitată după ce în 1977 se descoperă efectele sale nefrotoxice. (1-3) În prezent, Litiul este utilizat în tulburarea bipolară și ca adjuvant în depresie, schizofrenie, tulburarea schizoafectivă, anorexie nervoasă și bulimie, dar și pentru controlul agresivității la copii și la adulți. (1-4)

\section{PREZENTARE DE CAZ}

Bărbat în vârsta de 48 de ani, prezintă odinofagie și disfagie în context febril de 7 zile, cu de- 
but insidios al tremorului intențional la nivelul membrelor, cu predominanță la nivelul membrelor superioare, care s-a agravat progresiv până la mioclonii, însoțite de ataxie și ușoară dizartrie. De 4 zile prezintă greață și 3 vărsături alimentare, cu impotența hidratării orale de 24 de ore. Din antecedetele patologice ale pacientului reținem episoade depresive cu elemente psihotice și absența antecedentelor neurologice. Din 2012 este în tratament constant cu Venlafaxină (225 mg/zi) și Carbonat de Litiu. Ultimul dozaj al litemiei a fost în urmă cu 3 săptămâni, fiind 1,3 mEq/L (VN=0,7-1,2 mEq/l), scăzânduse doza la $450 \mathrm{mg} \times 3 /$ zi. Pacientul nu și-a administrat medicația psihiatrică de 48 de ore. La examenul obiectiv, pacientul este febril 38,1C, anxios, conștient, cooperant, orientat temporospaţial, mioclonii la nivelul membrelor cu predominanță la nivelul membrelor superioare accentuate în mișcare, probe de dismetrie pozitive, ataxie, fără deficit motor sau senzitiv, ușoară dizartrie, fără deficit la nivelul nervilor cranieni, RCP în flexie, ROT prezente, fără semne de iritație meningeală, limbă uscată deshidratată, hiperemie faringoamigdaliană cu hipertrofie amigdaliană și depozite pultacee la nivelul amigdalelor, echilibrat cardio-vascular $(\mathrm{TA}=120 / 80$ $\mathrm{mmHg}, \mathrm{AV}=80 / \mathrm{min}$ regulat) și respirator, se evidențiază bradicardia relativă în context febril. Examenul biologic evidențiază leucocitoză (23.000/microl) cu neutrofilie, sindrom inflamator ușor, hematocrit crescut cu hiponatremie ( $\mathrm{Na}=126 \mathrm{mmol} / \mathrm{l})$, hipopotasemie (K=2,8 mmol/l), retenție azotată (creatinină $=1,7 \mathrm{mg} / \mathrm{dl} \mathrm{VN}=0,7$ $1,1 \mathrm{mg} / \mathrm{dl}$ ), glicemie normală, LCR în limite normale, CT cerebral nativ în limite normale, fără semne de hipertensiune intracraniană, serologie HIV, TPHA/VDRL, Borrelia, herpes simplex 1,2, Chlamydia și Mycoplasma negative, exudat faringian pozitiv pentru streptococ beta hemolitic de grup $\mathrm{C}$, hemoculturile au rămas necrescute la 7 zile. Litemia efectuată la 2 zile de la internare și 4 zile de la stoparea administrării Carbonatului de litiu (intoleranță digestivă la domi- ciliu) evidențiază un nivel de $1,4 \mathrm{mEq} / \mathrm{l}$ cu VN între 0,6-1,2 mEq/L. Electrocardiograma (ECG) efectuată la internare indică ritm sinusal, scăderea amplitudinii, unde T cu ușoară subdenivelare a segmentului ST de 0,5 mm, fără unda U, cu interval QT normal. De la internare, anamneza și tabloul clinic ridică suspiciunea de intoxicație cu Litiu (având ca argumente ulterioare balanța hidroelectrolitică și, ulterior, litemia) în context de angină pultacee cu deshidratare secundară febrei și vărsăturilor, și aportului hidric scăzut (odinodisfagie), motiv pentru care se începe hidratarea parenterală și reechilibrarea hidroelectrolitică și tratament antibiotic cu Amoxicilină + acid clavulanic $1,2 \mathrm{~g}$ la 12 ore i.v. Consultul neurologic și psihiatric confirmă diagnosticul cu recomandarea de tratament cu Rivotril 0,5 mg x 2/zi, Convulex $500 \mathrm{mg} /$ zi și Efectin $75 \mathrm{mg} / \mathrm{zi}$. Puncția lombară care evidențiază LCR cu proteinorahie, glicorahie și celularitate normale, exclude o meningoencefalită (puțin probabilă în contextul clinic). Sub tratamentul administrat, evoluția pacientului este favorabilă, cu apirexie la 48 de ore de la debutul antibioterapiei și dispariția simptomatolgiei faringiene, normalizarea balanței hidroelectrolitice și a funcției renale cu remiterea treptată a manifestărilor neurologice până la 7 zile, când se decide externarea.

\section{DISCUṬII}

În literatura de specialitate sunt descrise puține cazuri de intoxicație cu Litiu în context infecțios - un caz descris în 2002 în context de gastroenterocolită (6), un caz de intoxicație cu Litiu în context de pneumonie fără recuperarea ataxiei (atrofie cerebeloasă secundară) (12) în 2008, un caz de creștere a litemiei în contextul tratamentului cu aciclovir pentru herpes zoster (8), însă sunt descrise multiple cazuri de supradozaj al tratamentului cu Litiu în contextul asocierii de medicație ce inhibă eliminarea renală sau în cazul unui aport hidric inadecvat (9).

Intoxicația cu Litiu este anunțată prin manifestări neurologice - tremor pronunțat (în spe- 
cial la nivelul membrelor superioare, este un tremor fin, intențional care apare destul de frecvent), dizartria și ataxia (efect toxic cu predilecție cerebelos) (7), simptome gastrointestinale (greață, diaree, vărsături), tablou clinic regăsit și în cazul prezentat anterior. De asemenea, pot apărea tulburări cardiace reprezentate de aritmii - datorate dezechilibrului hidroelectrolitic hipopotasemiei care derivă din efectul diuretic al Litiului, dar și din mecanismul de concurență electrolitică cu ionii de K de la nivel celular și renal (poliurie). $(1,4)$ În cazul nostru, potasemia a fost de $2,8 \mathrm{mEq} / \mathrm{l}$ și a fost corectată prompt cu normalizarea electrocardiogramei și cu evitarea tulburărilor de ritm cardiac.

Din particularitățile farmacocinetice ale Litiului menționăm timpul de înjumătățire, care este inițial de 1-3 zile și devine 2-4 zile după administrarea cronică (mai mult de $1 \mathrm{an}$ ), ceea ce poate duce la efectul cumulat al dozelor. $(1,4)$ În același timp, bariera hematoencefalică permite doar pasajul lent al ionilor de Litiu și de aceea intoxicația cu Litiu se remediază lent. Litiul nu se metabolizează hepatic și este excretat exclusiv renal. $(1,3,4)$ Concetrațiile plasmatice ale Litiului trebuie atent urmărite. Intervalul terapeutic general acceptat este 0,5 până la maxim 1,2 $\mathrm{mEq} / \mathrm{L}$ (3). În cazul pacientului nostru, litemia a fost 1,4 mEq/L la 4 zile de la întreruperea tratamentului. În literatură, intoxicația ușoară apare la o concentrație de 1,4-2,0 mEq/L și cuprinde vărsături, dureri abdominale, ataxie, tremor, incoerență verbală, nistagmus, letargie sau agitație și hipotonie. (4) Intoxicația medie apare la concentrații de 2,0-2,5 mEq/L și se manifestă prin fasciculații, mioclonii, hiperreflexivitate, convulsii, delir, sincopă, stupoare, comă. (4) Intoxicația severă survine la concentrații de peste 2,5 mEq/L când apar convulsii generalizate, oligurie, blocaj renal, aritmii cardiace și deces. (4) Așadar, pacientul a prezentat o intoxicație cu Litiu ușoară, dar cu apariția fasciculațiilor, miocloniilor și hiperreflexivitații, ce sunt caracteristice pentru intoxicația medie, care poate fi explicată prin realizarea târzie a litemiei și suspiciunea unei litemii mai mari anterior.

Măsurile terapeutice în intoxicația cu Litiu constituie o urgență medicală (4), fiind necesare încă de la ridicarea suspiciunii. Administrarea de Litiu trebuie oprită brusc, iar reechilibrarea balanței hidroelectrolitice este esențială (11). Investigarea clinică trebuie să includă examenul neurologic, cardiologic și psihiatric (10), și tratament adecvat, realizate și în cazul pacientului nostru. Investigarea paraclinică trebuie să cuprindă - dozajul seric al Litiului și al celorlalți electroliți, funcția renală și ECG. Se poate încerca emeza forțată, lavajul gastric și administrarea de polistiren sulfonat (în cazul intoxicației acute grave). Pentru pacienții cu concentrații de peste 4,0 mEg/L trebuie iniţiată hemodializa sau dializa peritoneală (11).

Riscul intoxicației cu Litiu este strâns legat de doză, deshidratare (balanță aport/excreție) și dietă hiposodată $(4,11)$. În contextul febril survenit în cadrul anginei pultacee și a odinofagiei cu disfagie, ce a dus la aport hidric scăzut și cu creșterea excreției prin creșterea catabolismului (febră, infecție bacteriană), condițiile favorizante ale creșterii litemiei au fost îndeplinite conducând la primele manifestări anunțate prin tremor și greață cu vărsături, cu accentuarea secundară a deshidratării, ceea ce a dus la un cerc vicios întrerupt eficient prin reechilibrarea hidroelectrolitică parenterală și prin tratamentul infecției bacteriene.

Așadar, deși intoxicația cu Litiu este o patologie rară, este esențial să fie prompt recunoscută, fiind o urgență medicală și, deci, necesitând tratament adecvat și chiar măsuri de terapie intensivă.

\section{CONCLUZII}

Intoxicația cu săruri de Litiu este rară în prezent datorită folosirii excepționale a Litiului și a dozajului strict al litemiei. Cazul prezentat se explică în contextul unui dezechilibru al balanței hidroelectrolitice, generat de deshidratare se- 
cundară infecției bacteriene acute, cu apariția febrei și a imposibilității unui aport hidric adecvat și, de asemenea, datorită afectării funcției renale. Toate acestea au avut ca efect, pe de o parte, scăderea eliminării litiului și, pe de altă parte, scăderea volumului intravascular cu creșterea concentrațiilor Litiului. Semnele intoxicației cu Litiu au apărut insidios cu manifestări digestive (greață, vărsături) care, însoțite de dis- fagia secundară anginei pultacee, au creat un cerc vicios între aport hidroelectrolic, excreție și litemie.

În concluzie, deși rareori întâlnit în clinicile de boli infecțioase, sindromul de intoxicație cu Litiu este obligatoriu să fie diagnosticat și tratat imediat dacă aspectul clinic și istoricul medical sugerează o intoxicație cu Litiu.

Conflict of interest: none declared Financial support: none declared 